\section{A CABBAGE-LIKE CECIDOMYIIDOUS GALL ON BIGELOVIA.}

\author{
BY C. H. TYLER TOWNSEND,
} KINGSTON, JAMAICA.

On June 21, 1892, a small bud-like gall was found on Bigelovia graveolens. It was quite abundant a few miles to the east of Gallo Spring, N. Mex. There were also found next day, June 22, west of Apache Spring.

Gall.-Length, 5 to $8 \frac{1}{2} \mathrm{~mm}$.; greatest basal width, 4 to $7 \mathrm{~mm}$. Small, bud-like, borne on sides of stems, to which the gall is attached by a very constricted base almost without length; formed of loosely overlapping stipules much like the cabbage gall on willow but not conical or compact. Greenish in color, or slightly yellowish, scantily covered with a fine white woolly pubescence. Stipules forming the gall rather broad at base, pointed at end or sometimes rounded, from I 2 to 20 in number, but not more than 8 or io showing on the outside, the tips of the rest joined and forming the terminal central tip of the gall. Inside the innermost of these, in a little slightly hardened cell, a single larva or pupa is found. Stipules with the woolly pubescence on the outer convex surface and on the edges, nearly or quite bare on the inner concave surface. The central pupal cell is thinly lined with the white woolly pubescence, and is about $3 \mathrm{~mm}$. long, by $\mathrm{I} \frac{3}{5}$ $\mathrm{mm}$, wide,

Described from 8 or 9 galls. This species, which is with hardly a doubt new, may be called Cecidomyia bigeloviae-brassicoides.

Mr. T. D. A. Cockerell records, on page to6 of vol. vi, West American Sci., the breeding of a cecidomyian from the galls of the trypetid Eurosta bigeloviae. If bred from the trypetid galls, it can hardly be the same as this species. He proposes the name C. bigeloviae for it, but without description of either gall or insect.

The CLICK of Ageronia.- In a paper on stridulation in certain Lepidoptera pub- lished by the Zoological society of London Mr. G. F. Hampson gives the first reasonable explanation of the clicking sound produced by Ageronia. He says: "On detaching and clearing a fore wing of Ageronia arethusa, I found there was a small pyriform membranous sac attached to the base of the inner margin of the fore wing, open anteriorly, and with a pair of curved chitinous hooks with spatulate extremities lying freely in front of it. It was obvious that this could not come

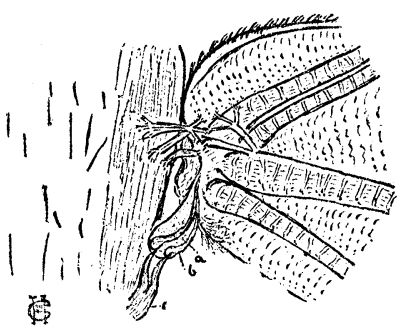

into contact with any of the nervures of the hind wing, and that no structure attached to the hind wing could act on it; and as there seemed to be a projection on the thorax in the immediate neighborhood, I cleared and denuded of scales a half insect with the wings still attached to the thorax, and could then see under a low power of the microscope that there was a pair of strong chitinous hooks attached to the thorax and that when the fore wing was moved up and down the spatulate ends of the chitinous hooks attached to the wing played against these, being released when the wing reached a certain angle, and I suggest that this is the cause of the clicking sound, the hooks acting as a tuning fork and the membranous sac as a sounding board." We owe to the favor of the Zoological society the opportunity to reproduce here his cut illustrative of the mechanism involved.

EARLy appearance of ANosia plexipPus.-On two very warm days in the early part of May, May II and I2, Mr. S. W. Den. 

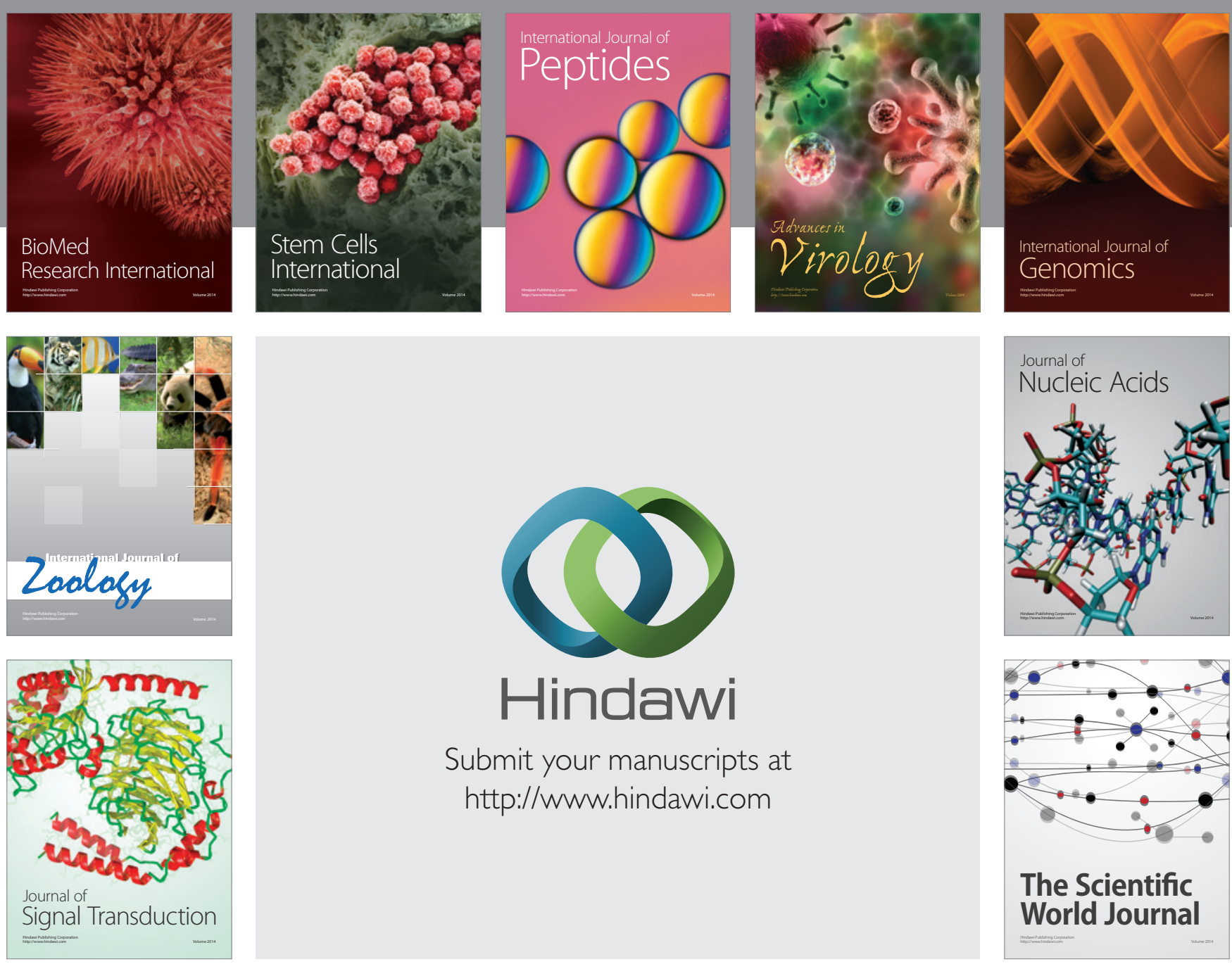

Submit your manuscripts at

http://www.hindawi.com
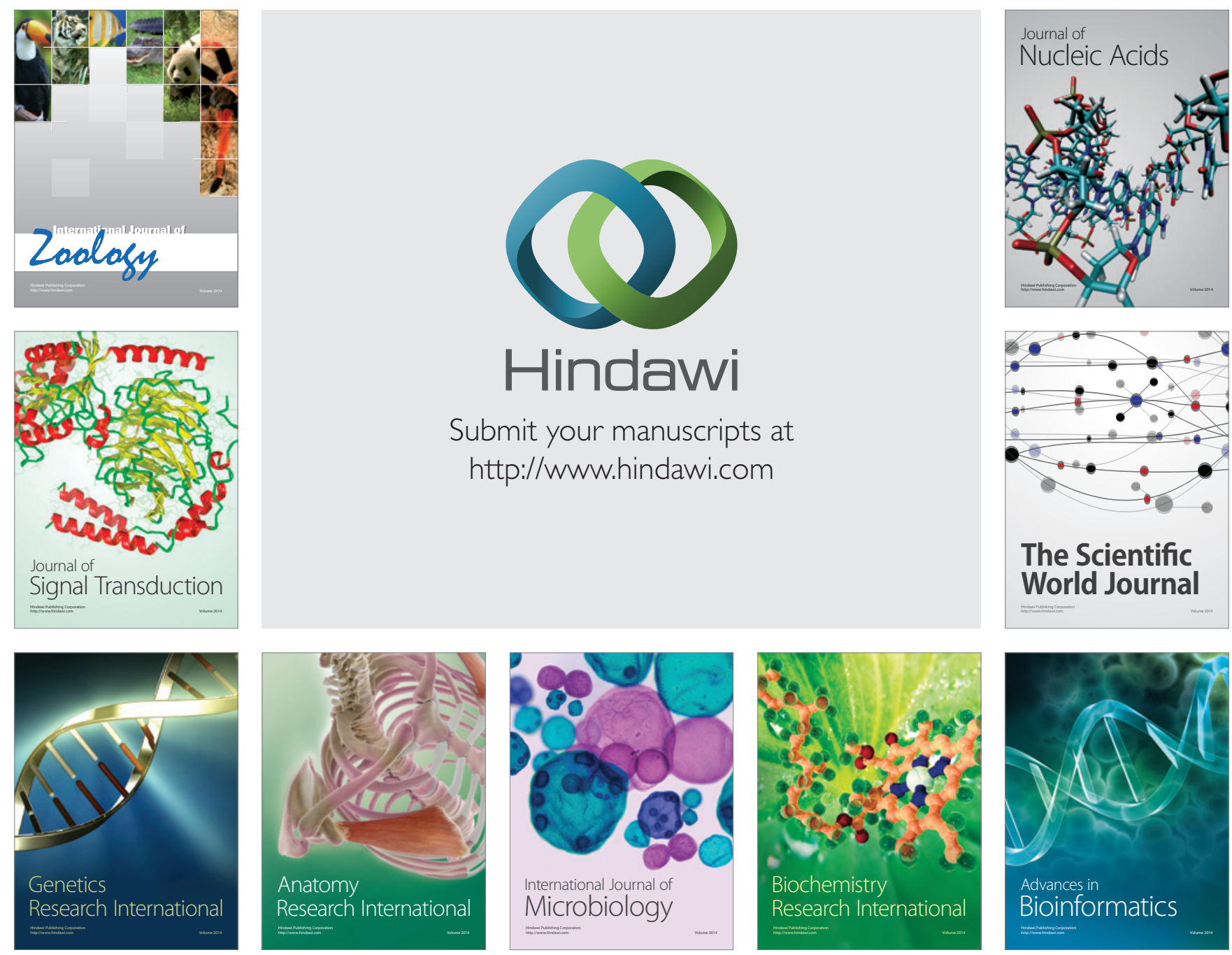

The Scientific World Journal
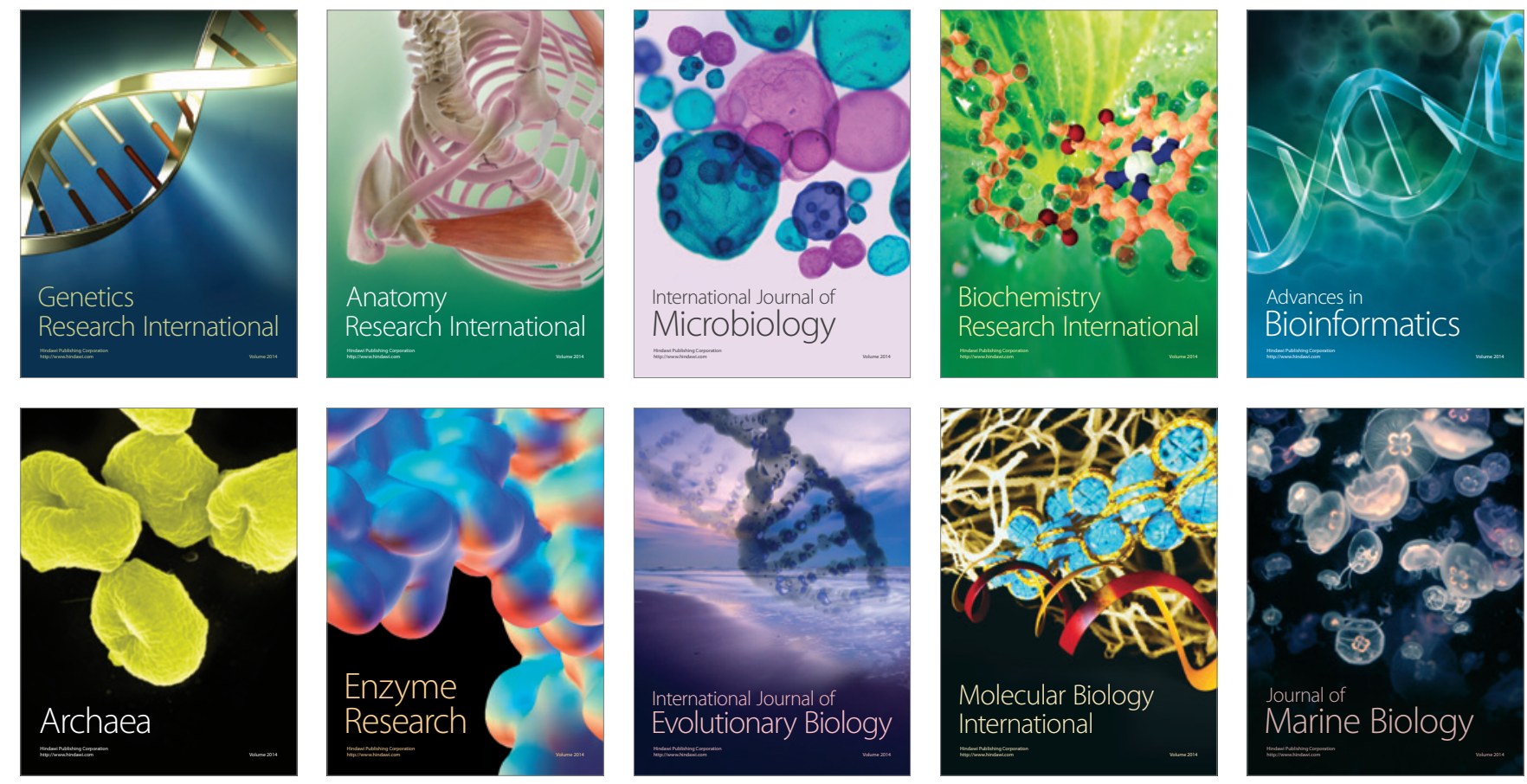